\title{
Pengaruh Keterampilan Mengajar Guru dan Fasilitas Belajar Terhadap Motivasi Belajar Siswa Kelas XI OTKP SMK Nasional Bandung
}

\author{
Nunik Dwi Handayani¹, Meta Arief ${ }^{2}$, Kurjono $^{3}$, Hari Mulyadi ${ }^{4}$ \\ 1,2,3,4 Program Studi Pendidikan Ekonomi \\ Universitas Pendidikan Indonesia \\ Bandung, Indonesia

\begin{abstract}
e-mail: nunikdwi@upi.edu*1,metaarief@upi.edu²,kurjono@upi.edu³, harimulyadi2012@gmail.com
\end{abstract}

Riwayat Artike Tanggal diajukan: 26 November 2021

Tanggal diterima : 8 Desember 2021

Tanggal dipublikasikan 15 Desember 2021

\begin{abstract}
Abstrak
Tujuan penelitian ini adalah untuk memperoleh informasi mengenai pengaruh keterampilan mengajar guru dan fasilitas belajar terhadap motivasi belajar siswa di Kelas XI OTKP SMK Nasional Bandung.Teori yang mendasari penelitian ini adalah teori motivasi aktualisasi diri maslow. Penelitian ini menggunakan pendekatan kuantitatif dengan metode survey dan instrumen yang digunakan berupa angket yang disebar kelas XI OTKP SMK Nasional Bandung sebanyak 105 responden. Teknik analisis data menggunakan analisis regresi. Penelitian yang dilakukan pada siswa kelas XI OTKP SMK Nasional Bandung memperoleh hasil bahwa Kondisi keterampilan mengajar, fasilitas belajar terhadap motivasi belajar siswa dalam kategori tinggi. Adapun Saran yang dapat diberikan dalam penelitian ini adalah pada variabel keterampilan mengajar guru untuk memberikan bekal kepada tenaga pendidik dengan adanya $I H T$, bimbingan teknis maupun workshop yang dapat meningkatkan kemampuan guru secara profesional sebagai variabel yang paling mendominasi. Pada variabel fasilitas belajar siswa dalam pembelajaran daring dapat memanfaatkan gadget serta fasilitas lainnya untuk menciptakan pembelajaran yang efektif.
\end{abstract}

Kata kunci: Keterampilan Mengajar Guru; Fasilitas Belajar; Motivasi Belajar Siswa

\begin{abstract}
The purpose of this study is to obtain information on the influence of teacher teaching skills and learning facilities on student learning motivation in Class XI OTKP SMK Nasional Bandung. The theory underlying this research is Maslow's self-actualization motivation theory. This research uses a quantitative approach with survey methods and instruments used in the form of questionnaires distributed class XI OTKP SMK Nasional Bandung as many as 105 respondents. Data analysis techniques use regression analysis. Research conducted on students of class XI OTKP SMK Nasional Bandung obtained the results that the condition of teaching skills, learning facilities against student learning motivation in the high category. The advice that can be given in this study is on the teacher's teaching skills variable to provide provision to educators with IHT, technical guidance and workshops that can improve the ability of teachers professionally as the most dominating variables. In the variables of learning facilities students in online learning can utilize gadgets and other facilities to create effective learning.
\end{abstract}

Keywords: Teacher Teaching Skills; Learning Facilities, Student Learning Motivation 


\section{PENDAHULUAN}

Tercapainya keberhasilan proses belajar dapat dilihat dari motivasi belajar siswa, Badaruddin (2015, hal. 19) mengatakan motivasi belajar siswa merupakan dorongan psikologis siswa yang melakukan suatu tindakan agar menguasai sesuatu pengetahuan, keterampilan yang baru berupa kemampuan, kemauan, kebiasaan dan sikap. Sementara itu Emda (2017, hal. 175) mengatakan motivasi belajar merupakan "sesuatu keadaan yang terdapat pada diri seseorang individu dimana ada suatu dorongan untuk melakukan sesuatu guna mencapai tujuan belajar".

Peneliti melakukan pra-penelitian dengan observasi awal menggunakan penyebaran angket ke kelas XI OTKP pada guru mata pelajaran Keuangan di SMK Nasional Bandung.

Tabel 1. Hasil Perhitungan Angket Observasi Awal

\begin{tabular}{lrc}
\hline $\begin{array}{c}\text { Rentang Nilai } \\
\text { Motivasi Belajar }\end{array}$ & $\begin{array}{r}\text { XI } \\
\text { OTKP }\end{array}$ & $\begin{array}{c}\text { Persentase } \\
(\%)\end{array}$ \\
\hline$>72,5$ & 6 & $34,6 \%$ \\
$>72,5$ & 13 & $65,4 \%$ \\
Total & 19 & $100 \%$ \\
\hline Sumber: Pengelolahan Data di Microsoft \\
Excel 2010
\end{tabular}

Berdasarkan tabel 1 dapat dilihat bahwa motivasi belajar siswa kelas XI OTKP (Otomatisasi Tata Kelola Perkantoran) ini masih dalam kategori rendah yang dibuktikan dengan pernyataan angket, bahwa kurangnyainisiatif dan antutias siswa pada saat guru mengajukan pertanyaan dan kurangnya semangat siswa dalam mengikuti pembelajaran daring terhambat oleh jaringan dan kuota.

Keterampilan mengajar (teacting skills) merupakan kompetensi pedagogik yang di miliki oleh guru mencakup kompleks karena merupakan suatu bentuk yang menyatuakan dari berbagai kompetensi secara utuh dan menyeluruh (Setyowati, 2020, hal. 79). Sementara itu Sundari dkk (2016, hal. 128) mengatakan bahwa Keterampilan mengajar merupakan kemampuan yang di miliki seoarang guru untuk menguasai bahan ajar, memilih metode yang tepat, menyajikan materi pelajaran dan dapat menguasai kelas dengan baik. selain itu yang dapat menunjang kegiatan pembelajaran adalah fasilitas yang memadai.

Fasilitas belajar adalah pendukung dalam proses pembelajaran secara langsung atau pun tidak langsung yang merupakan sarana dan prasarana yang dimiliki sekolah, oleh itu fasilitas belajar siswa diharapkan memadai dan sesuai dengan standar di sekolah pada umumnya (Dimyati, 2013, hal. 11). Prianto \& Putri (2017, hal. 17) mengatakan bahwa fasilitas belajar merupakan suatu benda baik bergerak maupun tiidak bergearak yang dapat memperlancar dan mempermudah proses pembelajaran sehingga dapat mencapai tujuan belajar.

Dalam hasil penelitian Arsana (2019) menunjukkan bahwa keterampilan mengajar guru memiliki pengaruh yang lebih dominan dalam menumbuhkan motivasi belajar siswa. Akan tetapi, tidak bisa dipungkiri bahwa fasilitas belajar juga memiliki andil dalam meningkatkan motivasi belajar sebab fasilitas belajar merupakan faktor penunjang yang sangat dibutuhkan didalam proses belajar.

Berdasarkan hasil penelitian Kurniawati (2017) menunjukkan bahwa ketersediaan fasilitas belajar berpengaruh secara signifikan terhadap prestasi belajar siswa tinggi rendahnya prestasi belajar siswa dapat dipengaruhi oleh beberapa faktor, baik itu faktor internal yang berasal dari siswa itu sendiri maupun faktor eksternal yang berasal dari luar diri sendiri.

Mengacu pada hasil penelitian terdahulu dapat diketahui bahwa keterampilan mengajar guru dan fasilitas belajar memiliki peranan yang sangat penting dalam menumbuh dan meningkatkan motivasi belajar siswa Kurniawati (2017). Sehingga guru dituntut memiliki keahlian atau kecakapan dalam mengajar. Kecakapan tersebut tidak hanya semata-mata pada kemampuan guru dalam mengelola kelas tetapi juga bagaimana guru tersebut dapat memanfaatkan dengan baik fasilitas belajar yang tersedia sebagai penunjang kelancaran proses belajar mengajar. Motivasi belajar siswa perlu terus 
p-ISSN : 2599-1418

e-ISSN : 2599-1426

dijaga dan dikembangkan, sebab, jika motivasi belajar siswa menurun maka dengan sendirinya siswa tidak akan mengikuti kegiatan belajar mengajar dengan baik. Maka perlu dioptimalkan bagaimana upaya dalam meningkatkan motivasi belajar siswa melalui peningkatan keterampilan mengajar dan fasilitas belajar yang diharapkan mampu untuk meningkatkan mutu kualitas pendidikan.

Keterampilan Mengajar Guru

Guru memiliki kontribusi yang besar terhadap keberhasilan pembelajaran di sekolah. Minat, bakat dan kemampuan Potensi siswa tidak akan berkembang jika tidak ada bantuan guru, guru juga perlu memperhatikan siswa. Individu siswa memiliki perbedaan yang sangat mendasar antara satu siswa dengan siswa lainnya, sehingga dalam proses pembelajaran guru, perlu memperhatikan dan memiliki keterampilan mengajar yang baik.

Keterampilan mengajar (teaching skills) merupakan kompetensi pedagogik yang dimiliki oleh guru mencakup kompleks karena merupakan suatu bentuk yang menyatuakan dari berbagai kompetensi secara utuh dan menyeluruh Setyowati (2020, hal. 79). Sementara itu Sundari dkk (2016, hal. 128) mengatakan bahwa Keterampilan mengajar merupakan kemampuan yang dimiliki seorang guru untuk menguasai bahan ajar, memilih metode yang tepat, menyajikan materi pelajaran dan dapat menguasai kelas dengan baik.

Fasilitas Belajar

Pada dasarnya fasilitas belajar adalah alat bantu yang digunakan dalam proses kegiatan belajar mengajar. Kenyataannya dilapangan motivasi belajar siswa sering tidak bias diprediksi dengan kondisi psikologi dan kelengkapan fasilitas belajar siswa. Lengkapnya fasilitas akan menunjang kegiatan belajar sehingga siswa giat untuk belajar. Dimyati (2013, hal. 11) mengatakan bahwa fasilitas belajar adalah pendukung dalam proses pembelajaran secara langsung maupun tidak langsung yang merupakan sarana dan prasarana yang dimiliki sekolah, oleh itu fasilitas belajar siswa diharapkan memadai dan sesuai
Jurnal Pendidikan Ekonomi Undiksha

Vol. 13 No.2 (2021)

dengan standar di sekolah pada umumnya. Sementara itu Prianto \& Putri (2017, hal. 17) mengatakan bahwa fasilitas belajar merupakan suatu benda baik bergerak maupun tidak bergerak yang dapat memperlancar dan mempermudah proses pembelajaran sehingga dapat mencapai tujuan belajar.

Fasilitas sekolah identik dengan sarana dan prasarana pendidikan. Sarana pendidikan adalah semua perangkat, peralatan, bahan, dan perabot yang secara langsung digunakan dalam proses pendidikan di sekolah dan prasarana pendidikan adalah semua perangkat kelengkapan dasar yang secara tidak langsung menunjang pelaksanaan proses pendidikan di sekolah. Fasilitas belajar adalah segala sesuatu yang diperlukan dalam proses belajar mengajar baik secara langsung maupun tidak langsung sehingga dapat berjalan lancar, efektif dan efisien (Nur, 2015, hal. 52).

Motivasi Belajar

Motivasi merupakan suatu perubahan yang terjadi pada diri seseorang yang muncul karena adanya gejala perasaan, kejiwaan dan emosi sehingga mendorong individu untuk melakukan atau bertindak sesuatuyang disebabkan karena kebutuhan, keinginan dan tujuan (Octavia 2020, hal. 54).

Uno dalam Badaruddin (2015, hal. 1819) motivasi belajar adalah dorongan internal maupun eksternal pada siswa-siswa yang sedang belajar untuk mengadakan perubahan tingkah laku yang pada umumnya dengan beberapa indikator atau unsur-unsur yang mendukung. hal ini yang memiliki peranan besar dalam kesuksesan mencapai tujuan belajar siswa. Dapat diklasifikasikan sebagai berikut:

1. Adanya hasrat atau keinginan untuk berhasil.

2. Adanya dorongan kebutuhan akan belajar.

3. Adanya harapan terhadap cita-cita.

4. Adanya penghargaan terhadap prestasi belajar.

5. Adanya kegiatan yang menarik dalam belajar.

6. Adaya lingkungan yang kondusif sehingga memungkinkan siswa dapat 
belajar dengan baik.

Grand theory yang dipakai dalam penelitian ini adalah teori yang dikembangkan oleh Maslow dikenal dengan hierarki kebutuhan Maslow (dalam Dimyati, 2009:81) berpendapat bahwa manusia mempunyai lima tingkat kebutuhan, yaitu: (1) kebutuhan fisiologis; seperti rasa lapar, haus, istirahat dan sex, (2) kebutuhan akan perasaan aman; tidak dalam arti fisik semata, akan tetapi juga mental, psikologikal dan intelektual, (3) kebutuhan sosial, (4) kebutuhan akan penghargaan diri, yang pada umumnya tercermin dalam berbagai simbol-simbol status, dan (5) kebutuhan akan aktualisasi diri. dalam arti tersedianya kesempatan bagi seseorang untuk mengembangkan potensi yang terdapat dalam dirinya sehingga berubah menjadi kemampuan nyata.

Berdasarkan paparan di atas tampak bahwa semakin tinggi persepsi responden terhadap keterampilan mengajar dan fasilitas belajar maka semakin tinggi motivasi belajar siswa, oleh karena itu model yang diajukan penulis adalah:

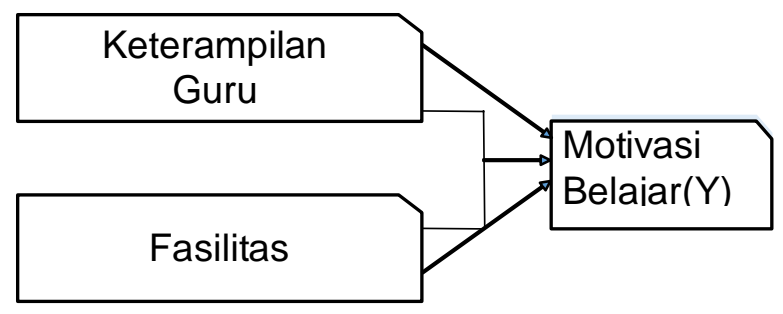

\section{METODE}

Gambar 1. Model Penelitian

Penelitian ini dilakukan dengan menggunakan metode survey pendekatan regresi yang bertujuan untuk mengetahui seberapa besar pengaruh keterampilan mengajar guru dan fasilitas belajar terhadap motivasi belajar siswa. instrument yang digunakan dalam penelitian ini berupa instrument kuisioner yang berisi berbagai pernyataan dari ketiga variabel dengan indicator yang sudah ditetapkan.

Populasi dan sampel dalam penelitian ini adalah siswa kelas XI OTKP SMK Nasional Bandung sebanyak 105 siswa.

Penelitian ini menggunakan teknik pengumpulan data yaitu dengan komunikasi tidak langsung dengan inventori yang digunakan bersifat tertutup yang artinya: sejumlah pernyataan yang ada pada setiap variabel telah disediakan alternative jawaban untuk dipilih oleh responden dengan menggunakan google form. untuk mengolah data yang sudah terkumpul peneliti menggunakan program IBM SPSS versi 25.

\section{HASIL DAN PEMBAHASAN}

Adapun hasil pengujian normalitas Variabel $\mathrm{X} 1, \mathrm{X} 2$ dan Variabel $\mathrm{Y}$ dengan berbantuan SPSS 25 dalam penelitian ini dapat dilihat pada tabel 2 berikut.

Tabel 2. Uji Normalitas Variabel X1, X2 dan Y

\section{One-Sample \\ Kolmogorov- \\ Smirnov Test}

$\mathrm{N}$

Normal

$\begin{array}{llr}\text { Parameters }{ }^{\mathrm{a}, \mathrm{b}} & \text { Mean } & , 0000000 \\ & \text { Std. } & 2,40595070 \\ & \text { Deviat } & 15.7 \\ & \text { ion } & 17.1 \\ \text { Most Extreme } & & , 108 \\ \text { Differences } & \text { Absolute } & , 108 \\ & \text { Positive } & -, 108 \\ & \text { Negative } & , 108 \\ \text { Test Statistic } & & , 200^{\mathrm{c}, \mathrm{d}} \\ \text { Asymp. Sig. } & & \end{array}$

Sumber: Hasil Pengolahan data pada IBM SPSS Statistics Version 25

Berdasarkan Tabel 2 di atas merupakan hasil pengolahan uji normalitas terhadap data yang didapatkan dalam penyebaran angket variabel $X 1$, variabel $X 2$ dan variabel $Y$. Seperti yang tertera pada tabel tersebut bahwa nilai signifikansi yang didapatkan sebesar 0,200c,d. Berdasarkan nilai signifikansinya, dapat disimpulkan bahwa variabel $\mathrm{X} 1, \mathrm{X} 2$ dan $\mathrm{Y}$ berdistribusi normal karena nilai signifikansi yang didapat lebih dari 0,05. 
Pengujian Hipotesis Regresi Linier Berganda

Tabel 3. Uji Regresi Linier Berganda

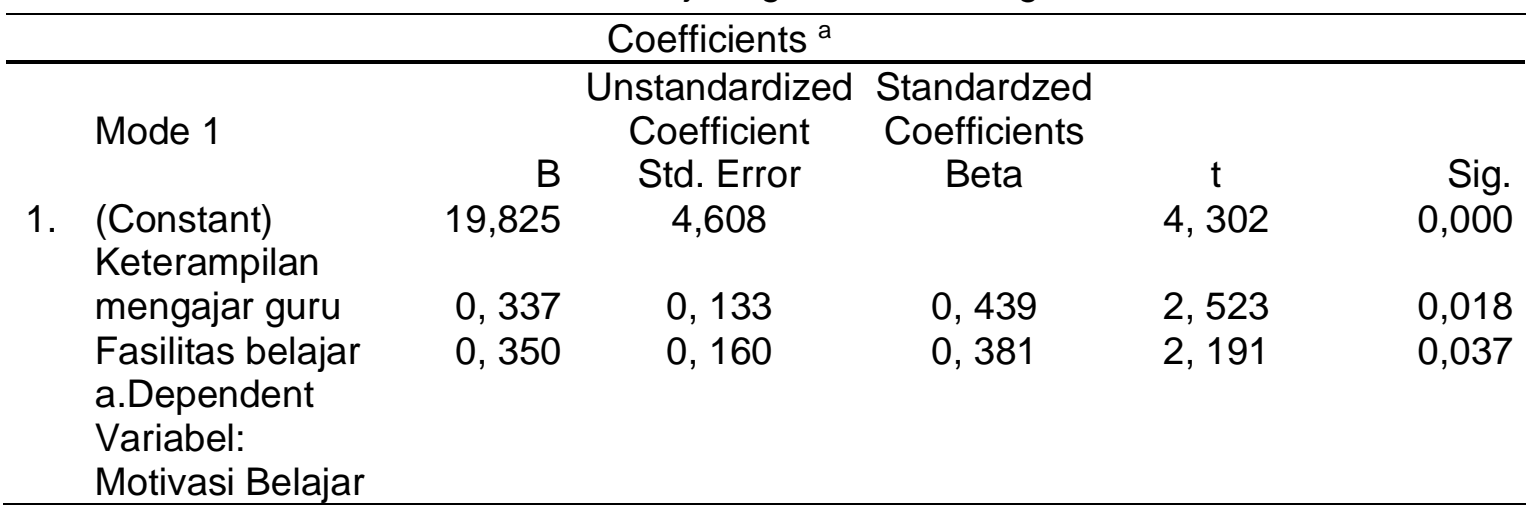

Sumber: Hasil Pengolahan data pada IBM SPSS Statistics Version 25

Berdasarkan hasil analisis regresi berganda diperoleh koefisien untuk variabel bebas $\mathrm{X} 1=0,337$ dan $\mathrm{X} 2=0,350$ dengan konstanta sebesar 19,825 sehingga diperoleh model persamaan regresi sebagai berikut:

$$
Y=19,825+0,337 X 1+0,350 X 2
$$

Keterangan:

Pengujian Hipotesis Koefisien Determinasi a. Nilai konstanta (Y) sebesar 19,825.

b. Koefisien regresi $\mathrm{X} 1$ (keterampilan mengajar guru) dari perhitungan linier berganda di dapat nilai koefisien $(\mathrm{b} 1)=$ 0,337 .

c. Koefisien regresi X2 (fasilitas belajar) dari perhitungan linier berganda di dapat nilai koefisien $(b 2)=0,350$.

Tabel 4. Hasil Uji Koefisien Determinasi

\begin{tabular}{rrccr}
\hline Model 1 & $\mathrm{R}$ & R Square & $\begin{array}{c}\text { Adjusted R } \\
\text { Square }\end{array}$ & $\begin{array}{c}\text { Std. Error of } \\
\text { the Estimate }\end{array}$ \\
\hline 1 & $0,753^{\mathrm{a}}$ & 0,567 & 0,535 & 2,53022
\end{tabular}

a.Predictors: (Constant), Fasilitas

Belajar, Keterampilan Mengajar

Guru

b.Dependent Variable: Motivasi

Belajar

Sumber: Hasil Pengolahan data pada IBM SPSS Statistics Version 25

Berdasarkan hasil nilai koefisien determinasi tabel 4 diatas diperoleh $R$ sebesar 0,753 serta besarnya kontribusi yang diberikan variabel Keterampilan mengajar guru dan fasilitas belajar $\mathrm{R}$ square sebesar0,567. Hal ini menunjukkan bahwa keterampilan mengajar guru dan fasilitas belajar secara bersama-sama berpengaruh terhadap motivasi belajar sebesar 56,7\%, yang berarti keterampilan mengajar guru dan fasilitas belajar masuk kriteria "kuat".
Pengujian Hipotesis Parsial (Uji t)

Dilakukannya pengujian hipotesis secara parsial untuk menguji seberapa signifikan pengaruh dari masing-masing variabel bebas.Jika nilai signifikansi > dari pada 0,05 , maka $\mathrm{H} 0$ diterima dan $\mathrm{H} 1$ ditolak.

a. Jika nilai signifikansi < daripada 0,05, maka $\mathrm{H} 0$ ditolak dan $\mathrm{H} 1$ diterima 
Tabel 5. Hasil Uji Hipotesis Secara Parsial (Uji t)

\begin{tabular}{llcr}
\hline \multicolumn{1}{c}{ Model } & $\mathrm{T}$ & \multicolumn{1}{c}{ Sig. } \\
\hline 1 & (Constant) & 4,302 & 0,000 \\
Keterampilan mengajar guru & 2,523 & 0,018 \\
& Fasilitas belajar & 2,191 & 0,037 \\
a. Dependent Variable: Motivasi Belajar & 3.12 & 2.75 \\
\hline
\end{tabular}

Sumber: Hasil Pengolahan data pada IBM SPSS Statistics Version 25

Dari hasil perhitungan tabel 5 di atas dapat diketahui bahwa hasil uji $\mathrm{t}$ untuk variabel keterampilan mengajar guru diperoleh hasil thitung 2,523> ttabel 2,051 dengan nilai signifikan sebesar $0,018<0,05$ maka Ho ditolak (Ha diterima). Jadi, dapat dikatakan bahwa keterampilan mengajar guru berpengaruh terhadap motivasi belajar siswa sehingga apabila keterampilan mengajar guru mengalami peningkatan maka motivasi belajar siswa juga akan meningkat.
Sedangkan untuk variabel fasilitas
belajar diperoleh hasil thitung 2,191>ttabel2,051 dengan nilai signifikan sebesar $0,037<0,05$ maka Ho ditolak ( $\mathrm{Ha}$ diterima). Jadi, dapat dikatakan bahwa fasilitas belajar berpengaruh terhadap motivasi belajar siswa sehingga apabila fasilitas belajar mengalami peningkatan maka motivasi belajar siswa juga akan meningkat.

Tabel 6. Hasil Uji Hipotesis Secara Simultan (Uji F)

\begin{tabular}{lccccc}
\hline & Model & Sum of & & Mean & \\
& Square & Df & Square & $F$ & Sig. \\
\hline Regression & & & & 17, & \\
Residual & 226,113 & 2 & 113,056 & 660 & \multirow{2}{*}{$000^{\text {b }}$} \\
Total & 172,854 & 27 & 6,402 & & \\
Tolal & 3967 & 29 & & &
\end{tabular}

a. Dependent Variable: Motivasi

Belajar

b. Predictors: (Constant),

Fasilitas belajar, Keterampilan

mengajar guru

Sumber: Hasil Pengolahan data pada IBM SPSS Statistics Version 25

Dari hasil perhitungan tabel 6 diatas diketahui bahwa Fhitung 17,660> Ftabel 3,340 dengan nilai signifikansi sebesar 0,000 $<0,05$. Dapat dikatakan bahwa secara simultan ada pengaruh keterampilan mengajar guru dan fasilitas belajar terhadap motivasi belajar siswa sehingga apabila keterampilan mengajar guru dan fasilitas belajar mengalami peningkatan maka motivasi belajar siswa juga akan meningkat dengan demikian maka model empiris disajikan dalam gambar sebagai berikut.

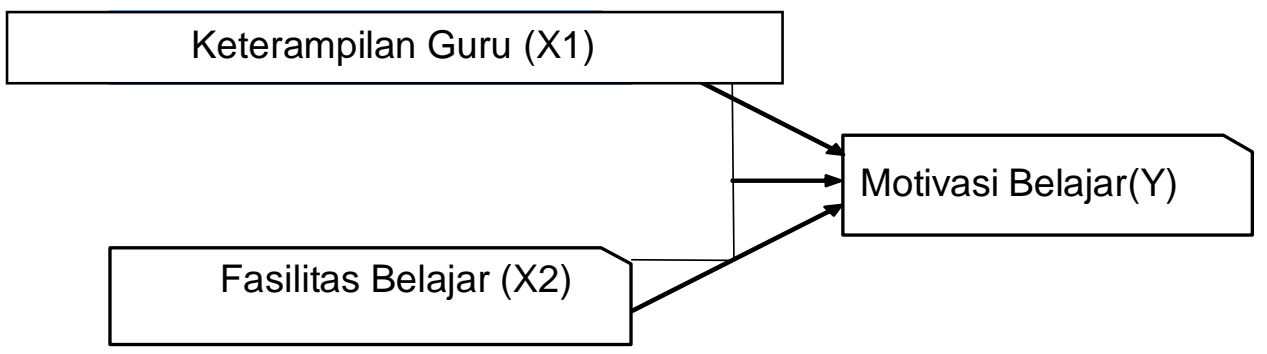

Gambar 2: Model Empiris 
p-ISSN : 2599-1418

e-ISSN : 2599-1426

\section{Pembahasan}

Pengaruh Keterampilan Mengajar Guru Terhadap Motivasi Belajar Siswa

Berdasarkan Hasil uji regresi dan hipotesis secara parsial (uji t) menunjukkan bahwa, variabel keterampilan mengajar guru diperoleh hasil thitung 2,523>ttabel2,051. hasilnya menyatakan bahwa keterampilan mengajar guru berpengaruh terhadap motivasi belajar siswa. Sedangkan hasil uji regresi koefisien regresi $\mathrm{X}_{1}$ (keterampilan mengajar guru) dari perhitungan linier berganda di dapat nilai koefisien (b1) = 0,337 . Hal ini berarti bahwa besarnya pengaruh keterampilan mengajar guru terhadap motivasi belajar siswa sebesar $30,7 \%$ menunjukan masuk kriteria "cukup" berpengaruh keterampilan mengajar guru terhadap motivasi belajar.

Sejalan dengan pernyataan Kurniawati (2017) bahwa terdapat pengaruh antara keterampilan mengajar guru terhadap motivasi belajar memberikan pengaruh yang cukup sebesar $36,7 \%$.

Pengaruh Fasilitas Belajar Terhadap Motivasi Belajar Siswa

Berdasarkan hasil uji regresi dan hipotesis secara parsial (uji t) menunjukkan bahwa variabel fasilitas belajar diperoleh hasil thitung sebesar 2,191>2,051 dengan nilai signifikan sebesar $0,037<0,05$ maka Ho ditolak (Ha diterima). Sedangkan hasil uji regresi koefisien regresiX2 (fasilitas belajar) dari perhitungan linier berganda di dapat nilai koefisien $(b 2)=0,350$. hasil koefisien determinasi secara sumbangan Efektif variabel fasilitas belajar sebesar $26 \%$.

Sejalan dengan pernyataan Kurniawati (2017) bahwa terdapat pengaruh fasilitas belajar terhadap motivasi belajar memberikan pengaruh yang cukupsebesar $23,4 \%$. Fasilitas belajar yang bertujuan mempermudah proses pembelajaran dengan adanya fasilitas belajar yang memadai maka proses pembelajaran akan lebih efektif dan dapat meningkatkan motivasi belajar siswa.
Jurnal Pendidikan Ekonomi Undiksha

Vol. 13 No.2 (2021)

Pengaruh Keterampilan Mengajar Guru dan Fasilitas BelajarTerhadap Motivasi Belajar Siswa

Berdasarkan hasil penelitian ini dapat diketahui bahwa keterampilan mengajar guru dan fasilitas belajar berpengaruh terhadap motivasi belajar siswa. Hal ini dibuktikan melalui hasil analisis data dalam uji normalitas yang di tunjukan bahwa nilai signifikansi yang didapatkan sebesar $0,200 \mathrm{c}, \mathrm{d}$.

Dalam uji regresi berganda menunjukan $Y=$ $19,825+0,337 X_{1}+0,350 X_{2}$, Nilai konstanta (Y) sebesar 19,825, Koefisien regresi $X_{1}$ (keterampilan mengajar guru) dari perhitungan linier berganda di dapat nilai koefisien (b1)

$=0,337$.

Hasil pengujian regresi linier telah didapat bahwa nilai $R$ square sebesar0,567. Hal ini menunjukkan bahwa keterampilan mengajar guru dan fasilitas belajar secara bersama-sama berpengaruh terhadap motivasi belajar sebesar $56,7 \%$ termasuk dalam kategori "kuat". dapat diketahui bahwa keterampilan mengajar guru lebih berpengaruh dominan terhadap motivasi belajar dibandingkan fasilitas belajar.

Dari hasil uji hipotesis secara Simultan (Uji F) diketahui bahwa Fhitung $=17,660$ dengan nilai signifikansi sebesar $0,000<$ 0,05.\$cara simultan terdapat pengaruh keterampilan mengajar guru dan fasilitas belajarterhadap motivasi belajar siswa.

Sejalan dengan Kurniawati (2017) bahwa terdapat pengaruh keterampilan mengajar guru dan fasilitas belajar terhadap motivasi belajar memberikan pengaruh yang cukup sebesar $37,89 \%$.

\section{SIMPULAN DAN SARAN}

Berdasarkan hasil penelitian dan pembahasan, maka dapat ditarik beberapa simpulan penelitian sebagai berikut:

1. Keterampilan mengajar guru berpengaruh positif terhadap motivasi belajar siswa. Hal ini menujukan bahwa semakin tinggi persepsi siswa terhadap keterampilan mengajar, semakin tinggi 
p-ISSN : 2599-1418

e-ISSN : 2599-1426

pula motivasi belajar siswa.

2. Fasilitas belajar berpengaruh positif terhadap motivasi belajar siswa. Hal ini menunjukan bahwa semakin tinggi persepsi siswa terhadap motivasi belajar.

3. Keterampilan mengajar guru dan fasilitas belajar berpengaruh terhadap motivasi belajar siswa.

Atas dasar kesimpulan dari hasil penelitian, maka penulis mengajukan beberapa saran yang sekiranya dapat bermanfaat bagi peningkatan efektivitas In House Training dalam meningkatkan keterampilan mengajar guru mata pelajaran produktif di sekolah. Pada variabel fasilitas belajar siswa dalam pembelajaran daring dapat memanfaatkan gadget serta fasilitas lainnya untuk menciptakan pembelajaran yang efektif.

\section{DAFTAR PUSTAKA}

Arsana, I. K. S. (2019). Pengaruh Keterampilan Mengajar Guru dan Fasilitas Belajar terhadap Motivasi Belajar Siswa. Sosial Horizon: Jurnal Pendidikan Sosial, 6(2), 269-282. https://doi.org/10.31571/sosial.v6i2.12 94

Badaruddin, A. (2015). Peningkatan Motivasi Belajar Peserta Didik Melalui Bimbingan Konseling. Jakarta: Abe Kreatifindo.

Dimyati. (2013). Belajar dan Pembelajaran. Jakarta: Rineka Cipta.

Emda, A. (2017). Kedudukan Motivasi Belajar Peserta Didik dalam Pembelajaran. Lantanida Journal, 5(2), 93-196.

Kurniawati, K. R. A. (2017). Efektivitas Model Pembelajaran Artikulasi dan Model Pembelajaran Talking Stick Terhadap Prestasi Belajar Matematika Ditinjau Dari Motivasi Belajar. Jurnal Teori dan Aplikasi Matematika (JTAM), 1(1), 510. https://doi.org/10.31764/jtam.v1i1.2

Nur, S. (2015). Korelasi Kelengkapan Fasilitas Belajar terhadap Hasil Belajar PKN di SMA 2 Polewai. Jurnal PEPATUDZU, 10(1), 47-67. https://doi.org/http://dx.doi.org/10.3532
Jurnal Pendidikan Ekonomi Undiksha

Vol. 13 No.2 (2021)

9/fkip.v10i1.38

Octavia, Y. (2020). Analisis Penerapan Metode Pembelajaran Cooperative Script dalam Proses Pembelajaran Ekonomi di Sekolah Menengah Atas Taruna Mandiri Pekanbaru. Skripsi. Universitas Islam Negeri Sultan Syarif Kasim Riau.

Prianto, A., \& Putri, T. H. (2017). Pengaruh Ketersediaan Fasilitas Belajar, Dukungan Orang Tua yang Dirasakan terhadap Motivasi dan Prestasi Belajar Siswa SMA PGRI Ngimbang Lamongan. Jurnal Pendidikan Ekonomi, Kewiraushaan, Bisnis, dan Manajemen (JPEKBM), 1(2), 13-38. https://doi.org/10.32682/JPEKBM.V112 .475

Setyowati, A. (2020). Melalui Pembinaan dan Pendampingan dalam Upaya Meningkatkan Kemampuan Guru dalam menyusun Rencana Pelaksanaan Pembelajaran di SLBC YPALB Karanganyar Kabupaten Karanganyar Semester I Tahun 2019/2020. KONVERGENSI, 32(7), 714.

Sundari, N., Susilowati, \& Wahyuningsih, Y. (2016). Optimalisasi Peningkatan Keterampilan Mengajar Mahasiswa Dengan Menerapkan Model Berbasis Masalah dalam Pembelajaran IPS di SD. EduHumaniora: Jurnal Pendidikan Dasar Kampus Cibiru, 6(2), 125-135. https://doi.org/10.17509/eh.v6i2.4577 